\title{
e Preliminary Results of a Randomized, Double- Blind, Controlled Trial of Fluoroscopic Lumbar Interlaminar Epidural Injections in Managing Chronic Lumbar Discogenic Pain Without Disc Herniation or Radiculitis
}

Laxmaiah Manchikanti, MD ${ }^{1}$, Kimberly A. Cash, RT ${ }^{1}$, Carla D. McManus, RN, BSN ${ }^{1}$, Vidyasagar Pampati, $\mathrm{MSc}^{1}$, and Ramsin M. Benyamin, $\mathrm{MD}^{2}$

From: ${ }^{1}$ Pain Management Center of Paducah, Paducah, KY; and ${ }^{2}$ Millennium Pain Center, Bloomington, IL.

Dr. Manchikanti is Medical Director of the Pain Management Center of Paducah, Paducah, KY, and Associate Clinical

Professor, Anesthesiology and Perioperative Medicine,

University of Louisville, Louisville, KY.

Kimberly A. Cash is a Research Coordinator at the Pain Management Center of Paducah, Paducah, KY. Carla D. McManus is a Nursing Administrator at the Pain Management Center of

Paducah, Paducah, KY.

Vidyasagar Pampati is a

Statistician at the Pain

Management Center of

Paducah, Paducah, KY.

Dr. Benyamin is the Medical

Director, Millennium Pain Center, Bloomington, IL, Clinical Assistant Professor of Surgery, College of Medicine, University of Illinois, Urbana-Champaign, IL.

Address correspondence: Laxmaiah Manchikanti, MD 2831 Lone Oak Road Paducah, Kentucky 42003 E-mail: drlm@thepainmd.com

Disclaimer: There was no external funding in the preparation of this manuscript.

Conflict of interest: None.

Manuscript received: 0 Accepted for publication:

Free full manuscript: www.painphysicianjournal.com
Background: Low back pain without disc herniation is the most common problem among chronic pain disorders. Epidural injections are commonly used interventions in managing chronic low back pain without disc herniation. However, little evidence exists regarding the effectiveness, indications, and medical necessity of lumbar epidural injections in managing axial low back pain without disc herniation or radiculitis.

Study Design: A randomized, double-blind, controlled trial.

Setting: An interventional pain management practice, a specialty referral center, a private practice setting in the United States.

Objectives: To evaluate the ability to provide effective and long-lasting pain relief with lumbar interlaminar epidural injections with local anesthetic with or without steroids in managing chronic low back pain not caused by disc herniation or radiculitis.

Methods: Patients were randomly assigned to one of 2 groups with Group I patients receiving local anesthetic only, whereas Group II patients received local anesthetic mixed with non-particulate betamethasone. Seventy patients were included in this analysis. Randomization was performed by computer-generated random allocation sequence by simple randomization.

Outcomes Assessment: Outcome measures included the Numeric Rating Scale (NRS), the Oswestry Disability Index $2.0(\mathrm{ODI})$, employment status, and opioid intake. The assessments were done at baseline, 3 months, 6 months, and 12 months post-treatment.

Significant pain relief and/or improvement in disability were defined as at least $50 \%$ improvement.

Results: Significant pain relief ( $\geq 50 \%$ ) was demonstrated in $74 \%$ of patients in Group I and $63 \%$ in Group II. Functional status improvement (reduction of $\geq 50 \%$ ) in the ODI scores was seen in $71 \%$ of patients in Group I and 60\% of patients in Group II. The overall average procedures per year were approximately 4

Limitations: The results of this study are limited by the lack of a placebo group and that it is a preliminary report of 35 patients in each group with a total of 70 patients.

Conclusion: Lumbar interlaminar epidural injections of local anesthetic with or without steroids was effective in $63 \%$ and $74 \%$ of patients with chronic function-limiting low back pain without facet joint pain, disc herniation, and/or radiculitis.

Key words: Chronic low back pain, lumbar interlaminar epidural injections, discogenic pain, disc herniation, radiculitis, local anesthetic, steroids, controlled comparative local anesthetic blocks

CLINICAL TRIAL: NCT00681447

Pain Physician 2010; 13:E279-E292 
ow back pain with or without lower extremity pain, not caused by disc herniation or radiculitis, has been identified as the most common problem among chronic pain disorders, causing significant economic, societal, and health impacts (1). Kuslich et al (2) showed that intervertebral discs, facet joints, ligaments, fascia, muscles, and nerve root dura are tissues capable of transmitting pain in the low back. A widespread interest was created in the disc as a source of pain in American medical literature by Mixter and Barr (3) in 1934 with their landmark description of the herniated nucleus pulposus. A year later, Mixter and Ayers (4) showed that radicular pain can occur without disc herniation. Subsequently, numerous investigators have described pain syndromes emanating from lumbar intervertebral discs without mechanical compression of the neural structures (5-10). The pathophysiology of low back pain and radicular pain is the subject of ongoing research and controversy with discogenic pain assuming a major role as a cause of non-specific low back pain, beyond disc herniation (11-14). In addition to the mechanical component, inflammation is an important factor in the pathophysiology of radicular and discogenic pain, with attributed neurotoxicity to many agents including phospholipase A2 (PLA2) and tumor necrosis factor (TNF) alpha, which play an essential role in intervertebral disc-induced pain (12-14).

Utilizing controlled diagnostic blocks, the prevalence of pain due to internal disc disruption was reported to be $39 \%$ in patients suffering with chronic low back pain (15), whereas primary discogenic pain was reported in $26 \%$ (5) when no other cause was suspected. Further, facet joint pain has been shown to be present in $21 \%$ to $41 \%$ of patients (16), whereas sacroiliac joint pain has been established in $10 \%$ to $38 \%$ of the selected population (17).

Epidural injections for managing chronic low back pain, whether the pain is caused by disc herniation or not, are commonly performed interventions in the United States. $(6-8,18-30)$. Friedly et al $(23)$ reported giving epidural injections in $36 \%$ of patients with axial low back pain. Manchikanti et al (26) reported a diagnosis other than disc herniation, radiculitis, or spinal stenosis in $47 \%$ of patients. However, most recommendations are limited to treating radicular pain with disc herniation. Even then, a randomized trial (31), 2 observational studies utilizing caudal approach $(32,33)$, and one study utilizing interlaminar approach (34) have been published evaluating the role of epidural injections in discogenic pain. The only interlaminar study evaluating discogenic pain by Butterman (34) reported effectiveness in improving pain and function at 3-month follow-up. However, at subsequent follow-up periods, the success rate declined. Further, in this study, one to 3 procedures were administered, rather than repeating them based on the return of pain and deterioration of functional status as others have done (31-37).

The majority of the literature on lumbar interlaminar epidurals, even for disc herniation and radiculitis, appears to be negative $(18,27-30)$. The variations in the evidence are based on numerous factors, including study design with or without fluoroscopy, study size, outcome parameters, follow-up, reviewer bias, and inappropriate evaluation of the study characteristics and conclusions (6-8,25-30,38-48). In general, evidence has been shown to be superior for caudal epidural injections, as well as transforaminal epidural injections, compared to an interlaminar approach $(18,19,21)$.

The underlying mechanism of action for epidurally administered local anesthetics and steroids has been described, though not well understood (49-61). The effect of local anesthetic with or without steroids has been reported to be the same in epidural injections and facet joint nerve blocks in clinical studies (31-33,3537,62-69). Further, an experimental evaluation of nerve root infiltration showed no significant difference with local anesthetic with or without steroids (61).

This study was undertaken to evaluate the role of lumbar interlaminar epidural injections in patients with chronic low back pain not caused by disc herniation, radiculitis, or facet joint pain. The study was designed to evaluate 120 patients. This preliminary report includes 70 patients completing a one-year follow-up.

\section{Methods}

This study was conducted in an interventional pain management practice, a specialty referral center, in a private practice setting in the United States. The study followed Consolidated Standards of Reporting Trials (CONSORT) guidelines $(70,71)$. The study protocol was approved by the Institutional Review Board (IRB) and registered with the U.S. Clinical Trial Registry. Its assigned number is NCT00681447.

\section{Participants}

Patients were recruited from new patients presenting to the center. They were assigned to one of 2 groups, with Group I patients receiving lumbar interlaminar epidural injections with $6 \mathrm{~mL}$ of local anesthetic 
(lidocaine $0.5 \%$ ); Group II patients received lumbar interlaminar epidural injections with $5 \mathrm{~mL}$ of local anesthetic (lidocaine $0.5 \%$ ) mixed with $6 \mathrm{mg}(1 \mathrm{~mL})$ of nonparticulate betamethasone.

\section{Interventions}

All patients were provided with the IRB-approved protocol and informed consent which described in detail all aspects of the study and the withdrawal process.

\section{Pre-Enrollment Evaluation}

The pre-enrollment evaluation included the exclusion of facet joint pain by controlled comparative local anesthetic blocks. Additional information gathered included demographic data, medical and surgical history with co-existing disease(s), radiologic investigations, physical examination, pain rating scores using the $\mathrm{Nu}$ meric Rating Scale (NRS), work status, opioid intake, and functional status assessment using the Oswestry Disability Index 2.0 (ODI).

\section{Inclusion Criteria}

Inclusion criteria included a negative diagnosis of lumbar facet joint pain by means of controlled comparative local anesthetic blocks; patients over the age of 18 years; patients with a history of chronic function-limiting low back pain of at least 6 months duration; and patients who were competent to understand the study protocol and provide voluntary, written informed consent and participate in outcome measurements.

Inclusion criteria also included no evidence of disc herniation and failure to improve with conservative management including but not limited to physical therapy, chiropractic manipulation, exercises, drug therapy, and bedrest.

Exclusion criteria included a positive response to lumbar facet joint pain by means of controlled comparative local anesthetic blocks; previous lumbar surgery; uncontrollable or unstable opioid use; uncontrolled psychiatric disorders; uncontrolled medical illness, either acute or chronic; any conditions that could interfere with the interpretation of the outcome assessments; pregnant or lactating women; and patients with a history or potential for adverse reaction(s) to local anesthetics or steroids.

\section{Description of Interventions}

All patients were evaluated with controlled comparative local anesthetic lumbar facet joint nerve blocks.
The process started with diagnostic facet joint nerve blocks with $0.5 \mathrm{~mL}$ of $1 \%$ lidocaine, followed by the blockade of facet joint nerves with $0.25 \%$ bupivacaine on separate occasions, with evaluation of concordant response with $80 \%$ pain relief $(16,72)$. Controlled, comparative local anesthetic blocks were also performed for suspected sacroiliac joint pain, with $2 \mathrm{~mL}$ of $1 \%$ lidocaine and $0.25 \%$ bupivacaine (17).

All lumbar interlaminar epidural procedures were performed by one physician in an ambulatory surgery setting, in a sterile operating room, utilizing fluoroscopy. Patients were in the prone position, under appropriate monitoring with intravenous access and sedation with midazolam and fentanyl. With sterile preparation, access to the epidural space was obtained, which was confirmed by an injection of non-ionic contrast. All procedures were performed either between L5 and S1 or at a higher level based on the patient's pain complaints. Following this, an injection of $6 \mathrm{~mL}$ of lidocaine hydrochloride $0.5 \%$ preservative free, or $5 \mathrm{~mL}$ of lidocaine mixed with $6 \mathrm{mg}$ of non-particulate betamethasone was carried out.

\section{Additional Interventions}

All patients underwent the treatments as assigned. Upon request, or if an emergency situation arose, a patient was unblinded. If a patient required additional lumbar interlaminar epidural injections, these were provided based on the response to the previous injection, with deterioration of pain relief to less than $50 \%$. Patients who were non-responsive and continued with conservative management were followed without further epidural injections with medical management, unless they requested unblinding.

\section{Co-Interventions}

Most patients were receiving opioid and nonopioid analgesics, adjuvant analgesics; some were involved in a therapeutic exercise program. If patients were improving significantly and the medical necessity for these drugs was lacking, medications were stopped or dosages were decreased. For some patients, based on medical necessity, dosages were increased. All patients continued previously directed exercise programs, as well as their work. Thus, in this study, there was no specific physical therapy, occupational therapy, bracing, or other interventions offered other than the study intervention. 


\section{Objectives}

The study was designed to evaluate the ability to provide effective and long-lasting pain relief with lumbar interlaminar epidural injections containing local anesthetic with or without steroids in managing chronic low back pain not caused by disc herniation or radiculitis; and to evaluate the differences between local anesthetic injections with or without steroids.

\section{Outcomes}

Multiple outcome measures were utilized. They included the NRS on a scale of $0-10$, the ODI on a $0-50$ scale, employment status, and opioid intake in terms of morphine equivalents. NRS represented no pain with a 0 and the worst pain imaginable with a 10. The ODI was utilized for functional assessment. The value and validity of the NRS and ODI have been reported $(39,40,73)$. Thresholds for the minimum clinically important difference for the ODI varied from a 4 to 15 point change from a total score of 50 (73). Recently, these thresholds have been questioned $(74,75)$. Significant pain relief or improvement and function was described as at least a $50 \%$ reduction in NRS or the ODI. The assessments were done at 3 months, 6 months, and 12 months post-treatment.

Based on the dosage frequency and schedule of the drug, the opioid intake was converted into morphine equivalents (76).

Employment and work status were determined based on employability at the time of enrollment. Employment and work status were classified into multiple categories such as employable, housewife with no desire to work outside, retired, or over the age of 65 . Patients who were unemployed due to pain, employed but on sick leave, or laid off were considered as employable.

The epidurals were considered to be successful if a patient obtained consistent relief with the first and second procedures of at least 3 weeks. All others were considered to be failures.

\section{Sample Size}

The sample size was calculated based on significant pain relief. Considering a 0.052 -sided significance level, a power of $80 \%$, and an allocation ratio of $1: 1$, 55 patients in each group were estimated (77). Allowing for a $10 \%$ attrition/non-compliance rate, 60 subjects were required.

Previous studies of interventional techniques have identified 50 to 60 patients as acceptable $(31,35-37,63-69,78,79)$.

\section{Randomization}

From a total of 120 patients, 60 patients were randomly assigned into each group.

\section{Sequence Generation}

Randomization was performed by computergenerated random allocations sequence by simple randomization.

\section{Allocation Concealment}

The operating room nurse assisting with the procedure randomized the patients and prepared the drugs appropriately.

\section{Implementation}

Participants were invited to enroll in the study if they met inclusion criteria. One of the 3 nurses assigned as coordinators of the study enrolled the participants and assigned participants to their respective groups.

\section{Blinding (Masking)}

Participants and those administering the interventions were blinded to group assignment. Both injectates were clear. The blinding was ensured by mixing the study patients with other patients receiving routine treatment. All patients chosen for one-year follow-up were selected by the statistician not participating in provision of the patients' care. The unblinding results were not disclosed to either the treating physician, other participants, or patients. Thus, the nature of blinding was not interrupted.

\section{Statistical Methods}

Statistical analysis included chi-squared statistic, Fisher's exact test, t-test, and paired t-test. Results were considered statistically significant if the $P$ value was less than 0.05 .

Chi-squared statistic was used to test the differences in proportions. Fisher's exact test was used wherever the expected value was less than 5; a paired t-test was used to compare the pre- and post-treatment results of average pain scores and ODI measurements at baseline versus 3 months, 6 months, and 12 months. For comparison of mean scores between groups, t-test was performed.

\section{Intent-to-Treat-Analysis}

An intent-to-treat-analysis was performed. Either the last follow-up data or initial data were utilized in the patients who dropped out of the study and no other data were available. 
Sensitivity analysis was performed utilizing best case, worst case, and last follow-up scores scenarios.

\section{Results}

\section{Participant Flow}

Figure 1 illustrates the participant flow.

\section{Recruitment}

The recruitment period lasted from January 2008 to March 2010.

\section{Baseline Data}

Table 1 illustrates the baseline demographic and clinical characteristics of each group. There were significant differences in the mean weight with Group I patients weighing more than Group II patients, duration of pain was also longer in Group II compared to Group I, and numeric rating scores were higher in Group I compared to Group II.

\section{Analysis of Data}

\section{Numbers Analyzed}

A schematic illustration of patient flow is provided in Fig. 1. The data were available in the majority of the included patients. An intent-to-treat analysis was performed due to non-available data on 8 occasions in Group I on a total of 4 patients, and on 11 occasions on 7 patients in Group II. Based on the number of treatments provided, lack of follow-up was found in 8 of 135 occasions (6\%) in Group I or 4 of 35 patients (11\%); whereas it was 11 of 132 (8\%) occasions in Group II with 7 of 35 patients $(20 \%)$ at least one time.

\section{Sensitivity Analysis}

A sensitivity analysis with changes in the numeric pain scale was performed utilizing the last followup score, best case scenario, and worst case scenario. There were no significant differences; therefore, the intention-to-treat analysis with last follow-up visit was used.

\section{Outcomes}

\section{Pain Relief}

Table 2 illustrates the NRS scores.

The proportion of patients with significant pain relief of $50 \%$ or greater is illustrated in Fig. 2 with $74 \%$ in Group I and 63\% in Group II.

\section{Functional Assessment}

Table 3 illustrates functional assessment results as assessed by the ODI. Significant improvement was seen in the functional status in both groups from baseline to one year.

Reduction of Oswestry scores of at least $50 \%$ was seen in $71 \%$ of patients in Group I and $60 \%$ of patients in Group II at 12 months (Fig. 3). There were no significant differences noted between the groups during the follow-up periods.

\section{Employment Characteristics}

Table 4 demonstrates employment characteristics for both groups.

\section{Opioid Intake}

Table 5 illustrates opioid intake.

\section{Therapeutic Procedural Characteristics}

Table 6 illustrates therapeutic procedural characteristics. Lumbar interlaminar procedures were performed in $91 \%$ of cases at L5/S1, and $9 \%$ of cases at L4/5.

There was no significant difference in average overall relief per year: in Group I it was $37.4 \pm 14.7$ weeks; in Group II it was $33.9 \pm 16.0$ weeks. The total number of procedures per year was $4.1 \pm 0.8$ in Group I and $4.0 \pm 0.9$ in Group II for successful subjects with relief of $40.7 \pm 10.2$ weeks in Group I and $37.7 \pm 12.4$ weeks in Group II.

Epidurals were considered to be successful if a patient obtained consistent relief with the first and second injections of at least 3 weeks.

\section{Changes in Weight}

There were no significant differences in change (gain or loss) in body weight from baseline in both groups (Table 7). As there were differences with baseline weight with higher weight in Group I, one-year follow-up weights were also significantly different, but there were no significant changes among the groups. In $40 \%$ of the patients in Group I without steroids and $54 \%$ of the patients in Group II with steroids lost weight; whereas, $43 \%$ of the patients in Group I without steroids and $32 \%$ of the patients in Group II with steroids gained weight.

\section{Adverse Events}

Of the 267 lumbar epidural procedures performed, there was one subarachnoid puncture. No postopera- 


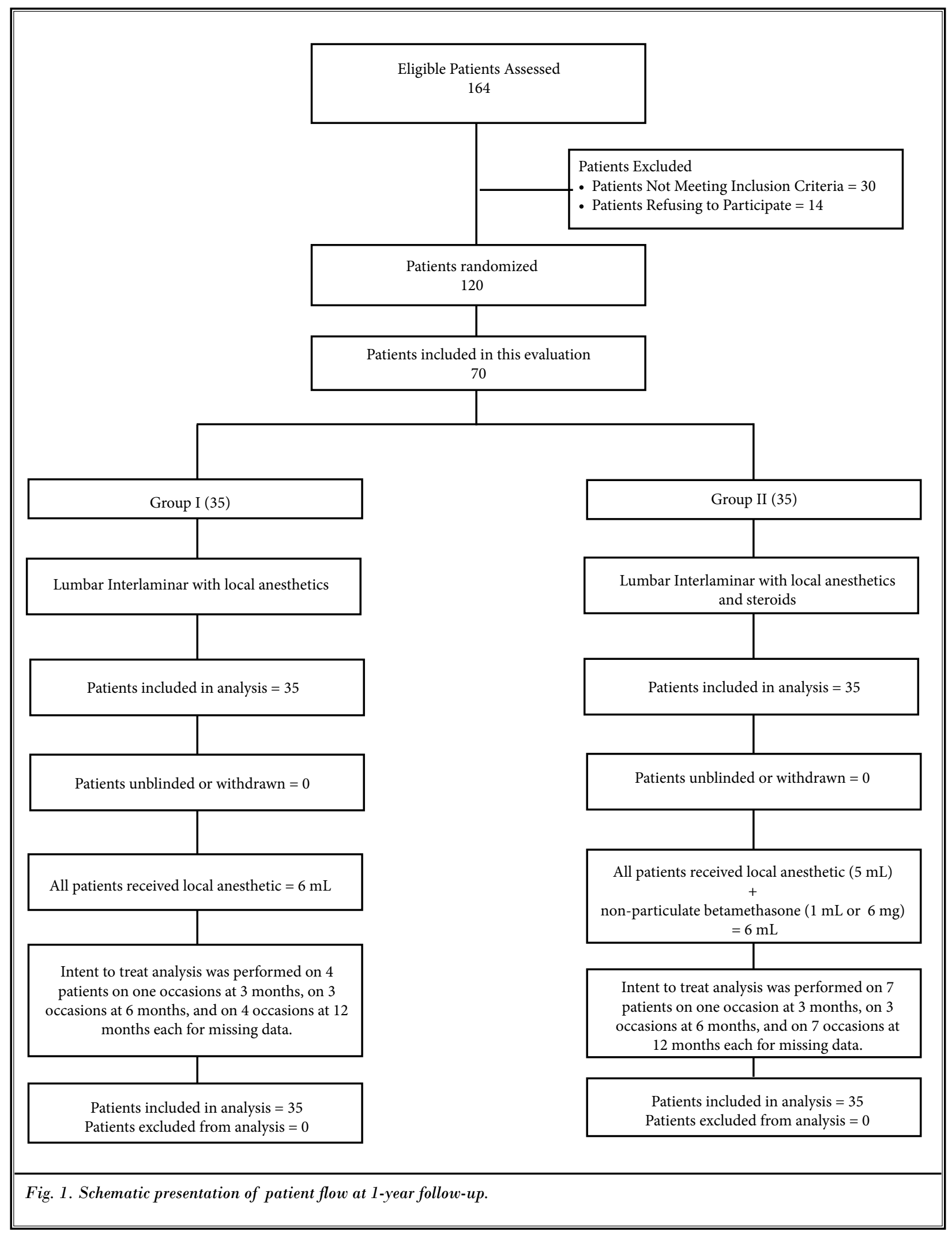


Table 1. Baseline demographic characteristics.

\begin{tabular}{|c|c|c|c|c|}
\hline & & $\begin{array}{c}\text { Group } 1 \\
(35)\end{array}$ & $\begin{array}{c}\text { Group II } \\
(\mathbf{3 5})\end{array}$ & $P$ value \\
\hline \multirow{2}{*}{ Gender } & Male & $26 \%(9)$ & $40 \%(14)$ & \multirow{2}{*}{0.203} \\
\hline & Female & $74 \%(26)$ & $60 \%(21)$ & \\
\hline Age & Mean \pm SD & $41.5 \pm 11.9$ & $42.0 \pm 12.5$ & 0.861 \\
\hline Weight & Mean \pm SD & $215.6 \pm 53.1$ & $169.0 \pm 44.9$ & 0.000 \\
\hline Height & Mean \pm SD & $66.3 \pm 3.9$ & $66.7 \pm 3.8$ & 0.601 \\
\hline Duration of pain (months) & Mean \pm SD & $77.3 \pm 74.6$ & $128.9 \pm 95.1$ & 0.014 \\
\hline \multirow{2}{*}{ Onset of pain } & Gradual & $63 \%(22)$ & $69 \%(24)$ & \multirow{2}{*}{0.615} \\
\hline & Injury & $37 \%(13)$ & $31 \%(11)$ & \\
\hline \multirow{4}{*}{ Pain distribution } & Back pain only & $44 \%(12)$ & $40 \%(14)$ & \multirow[b]{2}{*}{0.812} \\
\hline & $\begin{array}{c}\text { Back pain and leg pain } \\
\text { equal }\end{array}$ & $66 \%(23)$ & $60 \%(21)$ & \\
\hline & Unilateral & $17 \%(6)$ & $14 \%(5)$ & \multirow{2}{*}{1.000} \\
\hline & Bilateral & $83 \%(29)$ & $86 \%(30)$ & \\
\hline Numeric Rating Score & Mean \pm SD & $8.1 \pm 0.9$ & $7.6 \pm 0.9$ & 0.010 \\
\hline Oswestry Disability Index & Mean \pm SD & $30.2 \pm 3.8$ & $28.8 \pm 5.1$ & 0.214 \\
\hline
\end{tabular}

Table 2. Pain relief characteristics.

\begin{tabular}{|l|l|l|l||}
\hline \multirow{2}{*}{$\begin{array}{l}\text { Numeric } \\
\text { Rating Score }\end{array}$} & Group I (35) & Group II (35) & \multirow{2}{*}{ P value } \\
\cline { 2 - 3 } & Mean \pm SD & Mean \pm SD & \\
\hline Baseline & $8.1 \pm 0.9$ & $7.6 \pm 0.9$ & 0.010 \\
\hline 3 months & $3.7^{\star} \pm 1.0$ & $3.4^{*} \pm 1.1$ & 0.262 \\
\hline 6 months & $4.1^{*} \pm 1.2$ & $3.5^{*} \pm 1.2$ & 0.059 \\
\hline 12 months & $3.9^{*} \pm 1.2$ & $3.8^{*} \pm 1.3$ & 0.850 \\
\hline
\end{tabular}

tive headache was reported. One patient developed postoperative headache for 3 days without dural puncture, and another patient experienced weight gain due to high dose steroid administration due to an unrelated medical problem.

* indicates significant difference with baseline values $(\mathrm{P}<0.001)$

\section{$\square$ Group I 巴 Group II $\square$}

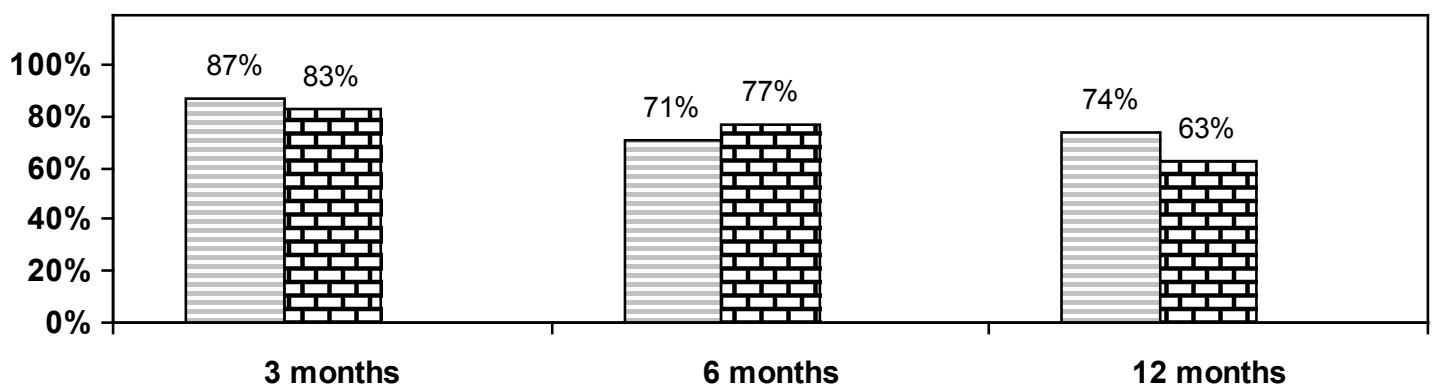

Fig. 2. Proportion of patients with significant pain relief $(\geq 50 \%)$. 


\section{Discussion}

The preliminary results of this study of 70 patients showed significant pain relief ( $\geq 50 \%$ ) in $74 \%$ in Group I without steroids and $63 \%$ in Group II with steroids with no significant differences noted over a one-year period.

Table 3. Functional assessment evaluated by Oswestry Disability Index.

\begin{tabular}{|l|l|l|l|}
\hline $\begin{array}{l}\text { Oswestry } \\
\text { Disability Index }\end{array}$ & $\begin{array}{l}\text { Group I } \\
(\mathbf{3 5})\end{array}$ & $\begin{array}{l}\text { Group II } \\
(\mathbf{3 5 )}\end{array}$ & P value \\
\hline & Mean \pm SD & Mean \pm SD & \\
\hline Baseline & $30.2 \pm 3.8$ & $28.8 \pm 5.1$ & 0.214 \\
\hline 3 months & $14.6^{*} \pm 4.1$ & $13.9^{*} \pm 4.8$ & 0.503 \\
\hline 6 months & $15.7^{*} \pm 5.1$ & $14.4^{*} \pm 4.9$ & 0.308 \\
\hline 12 months & $15.0^{*} \pm 5.2$ & $15.9^{*} \pm 6.9$ & 0.546 \\
\hline
\end{tabular}

* indicates significant difference with baseline values $(P<0.001)$
In addition, functional assessment measured by ODI also showed significant improvement, with at least a $50 \%$ reduction in Oswestry scores in $71 \%$ in Group I and $60 \%$ in Group II patients with no significant differences between the groups. The average procedures per year were approximately 4 with an average total relief per year of $37.4 \pm 14.7$ weeks in Group I and 33.9 \pm 16.0 weeks in Group II. Further, when patients were separated into successful and failed groups, the total relief per year was $40.7 \pm 10.2$ in Group I and $37.7 \pm$ 12.4 weeks in Group II among successful subjects; there was a very low response in failed subjects. This study provides modest results with an average relief of 6 to 10 weeks with the first and second procedures in the successful group, with an average relief of 11 to 12 weeks with subsequent procedures.

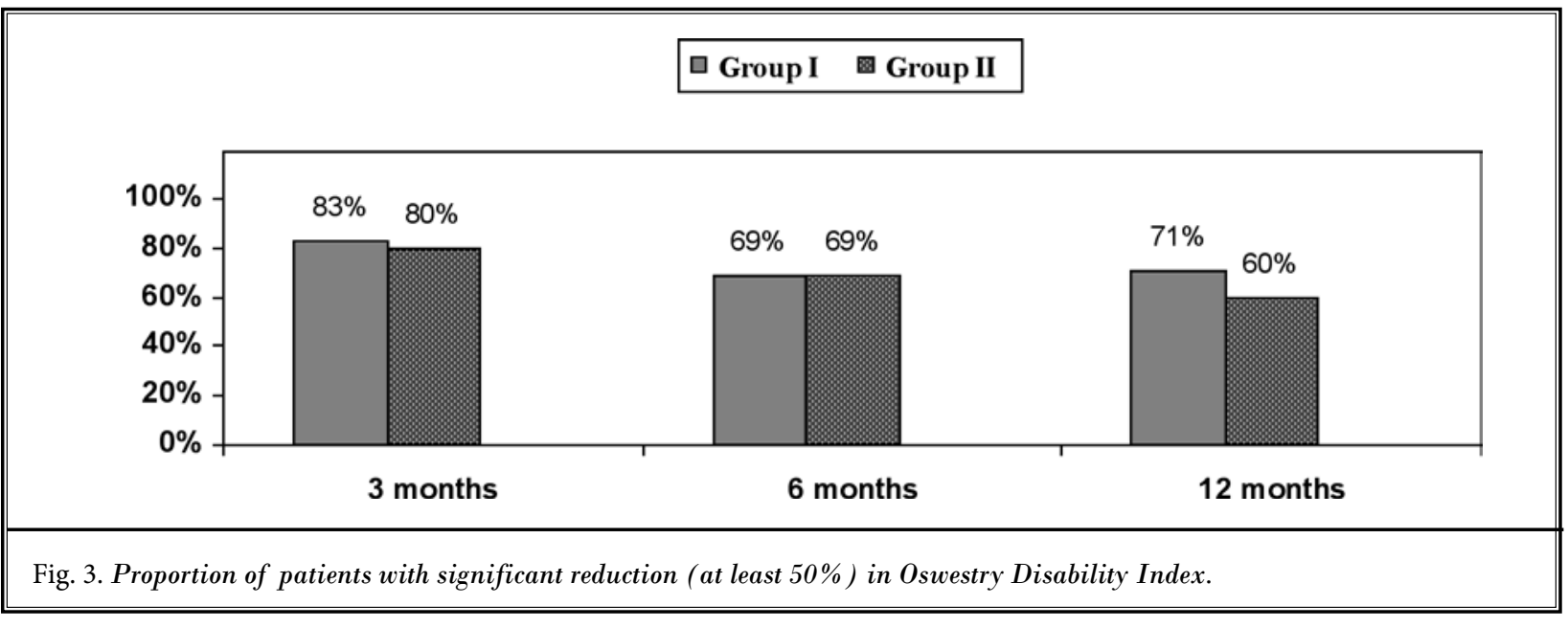

Table 4. Employment characteristics.

\begin{tabular}{|c|c|c|c|c|}
\hline \multirow{2}{*}{ Employment status } & \multicolumn{2}{|c|}{ Group I } & \multicolumn{2}{|c|}{ Group II } \\
\hline & Baseline & 12 months & Baseline & 12 months \\
\hline Employed part-time & 5 & 5 & 1 & 3 \\
\hline Employed full-time & 1 & 2 & 7 & 7 \\
\hline Unemployed (due to pain) & 2 & 1 & 0 & 0 \\
\hline Not working & 3 & 3 & 4 & 2 \\
\hline Eligible for employment & 11 & 11 & 12 & 12 \\
\hline Total Employed & 6 & 7 & 8 & 10 \\
\hline Housewife & 2 & 2 & 5 & 5 \\
\hline Disabled & 21 & 21 & 16 & 16 \\
\hline Retired & 1 & 1 & 2 & 2 \\
\hline Total Number of Patients & 35 & 35 & 35 & 35 \\
\hline
\end{tabular}


Table 5. Opioid intake (morphine equivalence mg).

\begin{tabular}{|l|c|c|c||}
\hline $\begin{array}{l}\text { Opioid Intake } \\
\text { (Morphine } \\
\text { Equivalence mg) }\end{array}$ & $\begin{array}{c}\text { Group I } \\
\mathbf{( 3 5 )}\end{array}$ & $\begin{array}{c}\text { Group II } \\
\mathbf{( 3 5 )}\end{array}$ & \multirow{2}{*}{ P value } \\
\cline { 2 - 3 } & $\begin{array}{c}\text { Mean } \pm \\
\text { SD }\end{array}$ & Mean \pm SD & \\
\hline Baseline & $52 \pm 61.2$ & $61 \pm 71.5$ & 0.569 \\
\hline 3 months & $39 \pm 29.3$ & $49 \# \pm 59.8$ & 0.374 \\
\hline 6 months & $42 \pm 32.3$ & $43 \# \pm 43.7$ & 0.882 \\
\hline 12 months & $41 \pm 32.9$ & $42 \# \pm 44.2$ & 0.908 \\
\hline
\end{tabular}

There is significant controversy regarding the medical necessity and indications for lumbar epidural injections, by either interlaminar approach or caudal approach. Multiple systematic reviews, guidelines, and other reviews have identified indications for lumbar interlaminar epidural injections in positive reports to treat radicular pain from herniated lumbar intervertebral discs. However, the evidence for other indications is limited. Three studies (31-33) have shown positive results using caudal epidural injections with or without steroids in patients with chronic function-limiting low

Table 6. Therapeutic procedural characteristics with procedural frequency, average relief per procedure, and average total relief in weeks over a period of one year.

\begin{tabular}{|c|c|c|c|c|c|c|}
\hline & \multicolumn{2}{|c|}{ Successful Subjects } & \multicolumn{2}{|c|}{ Failed Subjects } & \multicolumn{2}{|c|}{ Combined } \\
\hline & $\begin{array}{c}\text { Group I } \\
(32)\end{array}$ & $\begin{array}{c}\text { Group II } \\
(\mathbf{3 1})\end{array}$ & $\begin{array}{c}\text { Group I } \\
\text { (3) }\end{array}$ & $\begin{array}{c}\text { Group II } \\
(4)\end{array}$ & $\begin{array}{c}\text { Group I } \\
(35)\end{array}$ & $\begin{array}{c}\text { Group II } \\
(\mathbf{3 5})\end{array}$ \\
\hline 1st procedure relief & $\begin{array}{l}6.7 \pm 4.1 \\
(32)\end{array}$ & $\begin{array}{l}6.3 \pm 3.8 \\
(31)\end{array}$ & $\begin{array}{l}0.1 \pm 0.2 \\
(3)\end{array}$ & $\begin{array}{l}0.7 \pm 0.9 \\
(4)\end{array}$ & $\begin{array}{l}6.2 \pm 4.3 \\
(35)\end{array}$ & $\begin{array}{l}5.6 \pm 4.0 \\
(35)\end{array}$ \\
\hline 2 nd procedure relief & $\begin{array}{c}9.7 \pm 3.2 \\
(32)\end{array}$ & $\begin{array}{l}9.3 \pm 3.9 \\
(31)\end{array}$ & $\begin{array}{l}5.0 \\
(1)\end{array}$ & $\begin{array}{c}1.01 .4 \\
(2)\end{array}$ & $\begin{array}{c}9.6 \pm 3.3 \\
(33)\end{array}$ & $\begin{array}{c}8.8 \pm 3.5 \\
(33)\end{array}$ \\
\hline 3rd procedure relief & $\begin{array}{l}11.9 \pm 2.5 \\
(32)\end{array}$ & $\begin{array}{l}10.2 \pm 4.1 \\
(29)\end{array}$ & $\begin{array}{l}2.0 \\
(1)\end{array}$ & $\begin{array}{c}9.00 \\
(1)\end{array}$ & $\begin{array}{l}11.6 \pm 3.0 \\
(33)\end{array}$ & $\begin{array}{l}10.2 \pm 4.1 \\
\quad(30)\end{array}$ \\
\hline 4th procedure relief & $\begin{array}{l}11.9 \pm 4.4 \\
(23)\end{array}$ & $\begin{array}{l}11.7 \pm 2.9 \\
(23)\end{array}$ & - & $\begin{array}{c}3.00 \\
(1)\end{array}$ & $\begin{array}{c}11.9 \pm 4.4 \\
(23)\end{array}$ & $\begin{array}{c}11.3 \pm 3.3 \\
(24)\end{array}$ \\
\hline 5 th procedure relief & $\begin{array}{l}12.5 \pm 1.3 \\
(11)\end{array}$ & $\begin{array}{l}12.5 \pm 0.8 \\
\quad(10)\end{array}$ & - & - & $\begin{array}{l}12.5 \pm 1.3 \\
(11)\end{array}$ & $\begin{array}{l}12.5 \pm 0.8 \\
(10)\end{array}$ \\
\hline Number of procedures per year & $4.1 \pm 0.8$ & $4.0 \pm 0.9$ & $1.7 \pm 1.1$ & $2.0 \pm 1.4$ & $3.9 \pm 1.1$ & $3.8 \pm 1.1$ \\
\hline Average relief per procedure & $10.1 \pm 4.0$ & $9.4 \pm 3.9$ & $1.5 \pm 2.1$ & $2.1 \pm 3.0$ & $9.8 \pm 4.2$ & $9.0 \pm 4.3$ \\
\hline $\begin{array}{l}\text { Average relief per procedure 3rd } \\
\text { procedure and after }\end{array}$ & $12.0 \pm 3.1$ & $11.1 \pm 3.3$ & 2.0 & 6.0 & $11.9 \pm 3.3$ & $11.0 \pm 3.5$ \\
\hline Total relief per year (weeks) & $40.7 \pm 10.2$ & $37.7 \pm 12.4$ & $2.3 \pm 4.0$ & $4.3 \pm 6.6$ & $37.4 \pm 14.7$ & $33.9 \pm 16.0$ \\
\hline
\end{tabular}

Table 7. Characteristics of changes in weight.

\begin{tabular}{|c|c|c|c|}
\hline \multirow{2}{*}{ Weight (lbs) } & Group I (35) & Group II (35) & \multirow{2}{*}{$P$ value } \\
\hline & Mean \pm SD & Mean \pm SD & \\
\hline Weight at beginning & $215.6 \pm 53.1$ & $169.0 \pm 44.9$ & 0.000 \\
\hline Weight at one year & $215.6 \pm 56.6$ & $166.5 \pm 45.2$ & 0.000 \\
\hline Change & $0 \pm 13.2$ & $-2.5 \pm 11.7$ & 0.403 \\
\hline Lost weight & $40 \%(14)$ & $54 \%(19)$ & \multirow{3}{*}{0.481} \\
\hline No change & $17 \%(6)$ & $14 \%(5)$ & \\
\hline Gained weight & $43 \%(15)$ & $32 \%(11)$ & \\
\hline
\end{tabular}


back pain without disc herniation or radiculitis. In these studies, patients without facet joint pain were evaluated under fluoroscopy. Only one study (34) evaluated the role of interlaminar epidural steroids. It showed improvement at 3-month follow-up only. Interlaminar epidural injections were effective in managing discogenic pain (36). As illustrated in the present study, epidural injections may provide long-term relief with judicious use and appropriate evaluation in patients without facet joint pain.

The results of this evaluation may be generalizable to interventional pain management settings when using appropriate diagnostic techniques and when using fluoroscopic visualization. In the era of evidence-based medicine, pragmatic or practical clinical trials measuring effectiveness are considered more appropriate than explanatory trials measuring efficacy $(39,40,80-82)$. Thus, practical trials are best designed to provide the results of a treatment's benefit produced in routine clinical practice (83). In addition, a placebo-controlled trial measures absolute effect size and shows the existence of effect, whereas, an active control trial such as the present study, not only shows the existence of effect, but also compares therapies (83).

The study may be criticized for the lack of a placebo group, the fact that it is a preliminary analysis, and various other variables. The preliminary analyses of these results are justifiable, considering that no appropriate studies are available with one-year follow-up.

Even though unrealistic, placebo-controlled neural blockade has been misinterpreted $(84,85)$ and thus is not applicable for clinical consideration. Some have mistakenly reported that any local anesthetic injection which yields similar results as steroids is considered a placebo. However, these interpretations are inaccurate. Further, the difference between injections of sodium chloride solution and dextrose has been shown (86). The experimental and clinical findings from investigation of the electrophysiological effects of $0.9 \%$ sodium chloride and dextrose $5 \%$ in water solution have added new knowledge and controversy to multiple aspects of neural stimulation used in regional anesthesia. The potential inaccuracy created by $0.9 \%$ sodium chloride solution versus $5 \%$ dextrose has been described $(86,87)$. The evidence also has shown differing effects of sodium chloride solution when injected into either the disc, the facet joint, or paraspinal muscles $(88,89)$. Finally, clinical effectiveness of epidural injection of sodium chloride solution has been illustrated in multiple studies (90-92).
Finally, the differences in weight with significantly larger patients in Group I and significantly longer duration of pain in Group II with higher numeric pain rating scores in Group I may be considered as disadvantages. However, weight continued to remain similar to the baseline in both groups at end of the one-year. The influence of duration of pain may not be evident in this study similar to differences in numeric pain rating scores. These issues may be resolved in the final report or in future multi-center studies with large numbers of patients included.

The hypothesis of the effectiveness of a neural blockade implicates or alteration of interruption of nociceptive input, reflex mechanism of the afferent fibers, self-sustaining activity of the neurons, and the pattern of central neuronal activities $(6,49)$. Corticosteroids have been shown to reduce inflammation by inhibiting either the synthesis or release of a number of pro-inflammatory mediators and by causing a reversible local anesthetic effect (49-54). In contrast, local anesthetics have been described to provide short- to long-term symptomatic relief based on various mechanisms (5559,93-96). It has been described that local anesthetics may alter multiple pathophysiologic mechanisms involved in chronic pain, including noxious peripheral stimulation, excess nociceptive process resulting in the sensitization of the pain pathways at several neuronal levels, and excess release of neurotransmitters (5559,93-96). The long-lasting effect of local anesthetics in epidural injections and facet joint nerve blocks without steroids has been demonstrated in a multitude of studies (31-33,35-37,62-69,94-96). Sato et al (60) evaluated the prolonged analgesic effect of epidural bupivacaine in neuropathic pain in a rat model and concluded that repetitive administration of bupivacaine into the epidural space in rats exerts an analgesic effect, possibly by inducing a plastic change in nociceptive input. Further, Tachihara et al (61) showed in rats that nerve root infiltration prevented mechanical allodynia; however, no additional benefit from using corticosteroid was identified, suggesting that corticosteroid may be unnecessary for nerve root blocks.

\section{Conclusion}

The assessment of the preliminary results of this randomized, double-blind, controlled trial of lumbar interlaminar epidural injections in chronic function-limiting low back pain without facet joint pain, disc herniation, and/or radiculitis demonstrated effectiveness in $74 \%$ of the patients receiving local anesthetic only and 
$63 \%$ of patients receiving local anesthetic and steroids with an average of 4 procedures per year.

\section{Acknowledgments}

The authors wish to thank Sekar Edem for assistance in search of literature, Tom Prigge for manuscript review, and Tonie M. Hatton and Diane E. Neihoff, transcriptionists, for their assistance in preparation of this manuscript. We would like to thank the editorial board of Pain Physician for review and criticism in improving the manuscript.

\section{References}

1. Manchikanti L, Singh V, Datta S, Cohen SP, Hirsch JA. Comprehensive review of epidemiology, scope, and impact of spinal pain. Pain Physician 2009; 12:E35E70.

2. Kuslich SD, Ulstrom CL, Michael CJ. The tissue origin of low back pain and sciatica: A report of pain response to tissue stimulation during operation on the lumbar spine using local anesthesia. Orthop Clin North Am 1991; 22:181-187.

3. Mixter WJ, Barr JS. Rupture of the intervertebral disc with involvement of the spinal canal. N Eng J Med 1934; 211:210 215.

4. Mixter WJ, Ayers JB. Herniation or rupture of the intervertebral disc into the spinal canal. N Engl J Med 1935 213:385-395

5. Manchikanti L, Singh V, Pampati V, Damron KS, Barnhill RC, Beyer CD, Cash KA Evaluation of the relative contributions of various structures in chronic low back pain. Pain Physician 2001; 4:308-316.

6. Manchikanti L, Boswell MV, Singh V, Benyamin RM, Fellows B, Abdi S, Buenaventura RM, Conn A, Datta S, Derby R, Falco FJE, Erhart S, Diwan S, Hayek SM, Helm S, Parr AT, Schultz DM, Smith HS, Wolfer LR, Hirsch JA. Comprehensive evidence-based guidelines for interventional techniques in the management of chronic spinal pain. Pain Physician 2009; 12:699-802.

7. Manchikanti L, Boswell MV, Singh V, Derby R, Fellows B, Falco FJE, Datta S, Smith HS, Hirsch JA. Comprehensive review of neurophysiologic basis and diagnostic interventions in managing chronic spinal pain. Pain Physician 2009; 12:E71-E120.

8. Manchikanti L, Boswell MV, Datta S, Fellows B, Abdi S, Singh V, Benyamin RM, Falco FJE, Helm S, Hayek S, Smith HS. Comprehensive review of therapeutic interventions in managing chronic spinal pain. Pain Physician 2009; 12:E123E198.

9. Manchikanti L, Glaser S, Wolfer L, Derby
R, Cohen SP. Systematic review of lumbar discography as a diagnostic test for chronic low back pain. Pain Physician 2009; 12:541-559.

10. Wolfer L, Derby R, Lee JE, Lee SH. Systematic review of lumbar provocation discography in asymptomatic subjects with a meta-analysis of false-positive rates. Pain Physician 2008; 11:513-538.

11. Wheeler AH, Murrey DB. Chronic lumbar spine and radicular pain: Pathophysiology and treatment. Curr Pain Headache Rep 2002; 6:97-105.

12. Hadjipavlou AG, Tzermiadianos $M N$, Bogduk N, Zindrick MR. The pathophysiology of disc degeneration: A critical review. J Bone Joint Surg Br 2008; 90:1261-1270.

13. McCarron RF, Wimpee MW, Hudkins PG, Laros GS. The inflammatory effects of nucleus pulposus: A possible element in the pathogenesis of low back pain. Spine (Phila Pa 1976) 1987; 12:760764.

14. Olmarker K, Nordborg C, Larsson K, Rydevik B. Ultrastructural changes in spinal nerve roots induced by autologous nucleus pulposus. Spine (Phila $\mathrm{Pa}$ 1976) 1996; 27:411-414.

15. Schwarzer AC, Aprill CN, Derby R, Fortin J, Kine G, Bogduk N. The relative contributions of the disc and zygapophyseal joint in chronic low back pain. Spine (Phila Pa 1976) 1994; 19:801-806.

16. Datta S, Lee M, Falco FJE, Bryce DA, Hayek SM. Systematic assessment of diagnostic accuracy and therapeutic utility of lumbar facet joint interventions. Pain Physician 2009; 12:437460.

17. Rupert MP, Lee M, Manchikanti L, Datta S, Cohen SP. Evaluation of sacroiliac joint interventions: A systematic appraisal of the literature. Pain Physician 2009; 12:399-418.

18. Conn A, Buenaventura R, Datta S, Abdi $S$, Diwan S. Systematic review of caudal epidural injections in the management of chronic low back pain. Pain Physician
2009; 12:109-135.

19. Parr AT, Diwan S, Abdi S. Lumbar interlaminar epidural injections in managing chronic low back and lower extremity pain: A systematic review. Pain Physician 2009; 12:163-188.

20. Benyamin RM, Singh V, Parr AT, Conn A, Diwan S, Abdi S. Systematic review of the effectiveness of cervical epidurals in the management of chronic neck pain. Pain Physician 2009; 12:137-157.

21. Buenaventura RM, Datta S, Abdi S, Smith HS. Systematic review of therapeutic lumbar transforaminal epidural steroid injections. Pain Physician 2009; 12:233-251.

22. Manchikanti L, Giordano J. Physician payment 2008 for interventionalists: Current state of health care policy. Pain Physician 2007; 10:607-626.

23. Friedly J, Leighton C, Deyo R. Increases in lumbosacral injections in the Medicare population: 1994 to 2001. Spine (Phila Pa 1976) 2007; 32:1754-1760.

24. Manchikanti L, Singh V, Derby R, Schultz DM, Benyamin RM, Prager JP, Hirsch JA. Reassessment of evidence synthesis of occupational medicine practice guidelines for interventional pain management. Pain Physician 2008; 11:393482.

25. Manchikanti L, Singh V, Pampati V Smith HS, Hirsch JA. Analysis of growth of interventional techniques in managing chronic pain in Medicare population: A 10-year evaluation from 1997 to 2006. Pain Physician 2009; 12:9-34.

26. Manchikanti L, Pampati V, Boswell MV, Smith HS, Hirsch JA. Analysis of the growth of epidural injections and costs in the medicare population: A comparative evaluation of 1997, 2002, and 2006 data. Pain Physician 2010; 13:199-212.

27. American College of Occupational and Environmental Medicine (ACOEM). Low back Disorders. In: Occupational Medicine Practice Guidelines: Evaluation and Management of Common Health Problems and Functional Recovery of 
Workers, Second Edition. American College of Occupational and Environmental Medicine Press, Elk Grove Village, 2007.

28. Dennison PL, Kennedy CW. Official Disability Guidelines. 15th ed. Work Loss Data Institute, 2010.

29. Staal JB, de Bie R, de Vet HC, Hildebrandt $J$, Nelemans $P$. Injection therapy for subacute and chronic low-back pain. Cochrane Database Syst Rev 2008; 3:CD001824.

30. Chou R, Atlas SJ, Stanos SP, Rosenquist RW. Nonsurgical interventional therapies for low back pain: A review of the evidence for an American Pain Society clinical practice guideline. Spine (Phila Pa 1976) 2009; 34:1078-1093.

31. Manchikanti L, Cash KA, McManus CD Pampati V, Smith HS. Preliminary results of randomized, equivalence trial of fluoroscopic caudal epidural injections in managing chronic low back pain: Part 1. Discogenic pain without disc herniation or radiculitis. Pain Physician 2008; 11:785-800.

32. Manchikanti L, Singh V, Rivera JJ, Pampati V, Beyer CD, Damron KS, Barnhill RC. Effectiveness of caudal epidural injections in discogram positive and negative chronic low back pain. Pain Physician 2002; 5:18-29.

33. Manchikanti L, Pampati V, Rivera J, Beyer CD, Damron KS, Barnhill RC. Caudal epidural injections with Sarapin steroids in chronic low back pain. Pain Physician 2001; 4:322-335.

34. Butterman GR. The effect of spinal steroid injections for degenerative disc disease. Spine / 2004; 4:495-505.

35. Manchikanti L, Singh V, Falco FJE, Cash KA, Pampati V. Evaluation of the effectiveness of lumbar interlaminar epidural injections in managing chronic pain of lumbar disc herniation or radiculitis: A randomized, double-blind, controlled trial. Pain Physician 2010; 13:343-355.

36. Manchikanti L, Cash KA, Pampati V Wargo BW, Malla Y. Cervical epidural injections in chronic discogenic neck pain without disc herniation or radiculitis: Preliminary results of a randomized, double-blind, controlled trial. Pain Physician 2010; 13:E265-E278.

37. Manchikanti L, Cash KA, Pampati V, Wargo BW, Malla Y. The effectiveness of fluoroscopic cervical interlaminar epidural injections in managing chronic cervical disc herniation and radiculitis:
Preliminary results of a randomized, double-blind, controlled trial. Pain Physician 2010; 13:223-236.

38. Manchikanti L. Evidence-based medicine, systematic reviews, and guidelines in interventional pain management: Part 1: Introduction and general considerations. Pain Physician 2008; 11:161-186.

39. Manchikanti L, Hirsch JA, Smith HS. Evidence-based medicine, systematic reviews, and guidelines in interventional pain management: Part 2: Randomized controlled trials. Pain Physician 2008, 11:717-773.

40. Manchikanti L, Benyamin RM, Helm S, Hirsch JA. Evidence-based medicine, systematic reviews, and guidelines in interventional pain management: Part 3: Systematic reviews and meta-analysis of randomized trials. Pain Physician 2009; 12:35-72.

41. Manchikanti L, Singh V, Smith HS, Hirsch JA. Evidence-based medicine, systematic reviews, and guidelines in interventional pain management: Part 4: Observational studies. Pain Physician 2009; 12:73-108.

42. Manchikanti L, Derby R, Wolfer LR, Singh V, Datta S, Hirsch JA. Evidencebased medicine, systematic reviews, and guidelines in interventional pain management: Part 5. Diagnostic accuracy studies. Pain Physician 2009; 12:517-540.

43. Manchikanti L, Falco FJE, Boswell MV, Hirsch JA. Facts, fallacies, and politics of comparative effectiveness research: Part I. Basic considerations. Pain Physician 2010; 13:E23-E54.

44. Manchikanti L, Falco FJE, Boswell MV Hirsch JA. Facts, fallacies, and politics of comparative effectiveness research: Part 2 - Implications for interventional pain management. Pain Physician 2010; 13:E55-E79.

45. Manchikanti L, Datta S, Derby R, Wolfer LR, Benyamin RM, Hirsch JA. A critical review of the American Pain Society clinical practice guidelines for interventional techniques: Part 1. Diagnostic interventions. Pain Physician 2010; 13: E141-E174.

46. Manchikanti L, Datta S, Gupta S, Munglani $R$, Bryce DA, Ward SP, Benyamin RM, Sharma ML, Helm II S, Fellows B, Hirsch JA. A critical review of the American Pain Society clinical practice guidelines for interventional techniques:
Part 2. Therapeutic interventions. Pain Physician 2010; 13E215-E263.

47. Manchikanti L, Singh V, Derby R, Helm S, Trescot AM, Staats PS, Prager JP, Hirsch JA. Review of occupational medicine practice guidelines for interventional pain management and potential implications. Pain Physician 2008; 11:271-289.

48. Manchikanti L, Singh V, Helm S, Trescot AM, Hirsch JA. A critical appraisal of 2007 American College of Occupational and Environmental Medicine (ACOEM) practice guidelines for interventional pain management: An independent review utilizing AGREE, AMA, IOM, and other criteria. Pain Physician 2008; 11:291-310.

49. Manchikanti L. Role of neuraxial steroids in interventional pain management. Pain Physician 2002; 5:182-199.

50. Byrod G, Otani K, Brisby H, Rydevik B, Olmarker K. Methylprednisolone reduces the early vascular permeability increase in spinal nerve roots induced by epidural nucleus pulposus application. J Orthop Res 2000; 18:983-987.

51. Hayashi N, Weinstein JN, Meller ST, Lee HM, Spratt KF, Gebhart GF. The effect of epidural injection of betamethasone or bupivacaine in a rat model of lumbar radiculopathy. Spine (Phila Pa 1976) 1998; 23:877-885.

52. Lee HM, Weinstein JN, Meller ST, Hayashi N, Spratt KF, Gebhart GF. The role of steroids and their effects on phospholipase A2: An animal model of radiculopathy. Spine (Phila Pa 1976) 1998; 23:1191-1196.

53. Minamide A, Tamaki $\mathrm{T}$, Hashizume $\mathrm{H}$, Yoshida M, Kawakami M, Hayashi N. Effects of steroids and lipopolysaccharide on spontaneous resorption of herniated intervertebral discs: An experimental study in the rabbit. Spine (Phila Pa 1976) 1998; 23:870-876.

54. Pasqualucci $A$, Varrassi $G$, Braschi $A$, Peduto VA, Brunelli $A$, Marinangeli $F$, Gori F, Colò F, Paladín A, Mojoli F. Epidural local anesthetic plus corticosteroid for the treatment of cervical brachial radicular pain: Single injection verus continuous infusion. Clin J Pain 2007; 23:551-557.

55. Mao J, Chen LL. Systemic lidocaine for neuropathic pain relief. Pain 2000; 87:7-17.

56. Pasqualucci A. Experimental and clinical studies about the preemptive anal- 
gesia with local anesthetics. Possible reasons of the failure. Minerva Anestesiol 1998; 64:445-457.

57. Lavoie PA, Khazen T, Filion PR. Mechanisms of the inhibition of fast axonal transport by local anesthetics. Neuropharmacology 1989; 28:175-181.

58. Bisby MA. Inhibition of axonal transport in nerves chronically treated with local anesthetics. Exp Neurol 1975; 47:481-489.

59. Cassuto J, Sinclair R, Bonderovic M Anti-inflammatory properties of local anesthetics and their present and potential clinical implications. Acta Anaesthesiol Scand 2006; 50:265-282.

60. Sato C, Sakai A, Ikeda Y, Suzuki H, Sakamoto A. The prolonged analgesic effect of epidural ropivacaine in a rat model of neuropathic pain. Anesth Analg 2008; 106:313-320.

61. Tachihara H, Sekiguchi M, Kikuchi S, Konno S. Do corticosteroids produce additional benefit in nerve root infiltration for lumbar disc herniation. Spine (Phila Pa 1976) 2008; 33:743-747.

62. Riew KD, Park JB, Cho YS, Gilula L, Patel A, Lente LG, Bridwell KH. Nerve root blocks in the treatment of lumbar radicular pain. A minimum five-year follow-up. J Bone Joint Surg Am 2006; 88:1722-1725.

63. Manchikanti L, Singh V, Falco FJ, Cash KA, Pampati V. Lumbar facet joint nerve blocks in managing chronic facet joint pain: One-year follow-up of a randomized, double-blind controlled trial: Clinical Trial NCT00355914. Pain Physician 2008; 11:121-132.

64. Manchikanti L, Singh V, Falco FJ, Cash KA, Fellows B. Cervical medial branch blocks for chronic cervical facet joint pain: A randomized double-blind, controlled trial with one-year follow-up. Spine (Phila Pa 1976) 2008; 33:18131820.

65. Manchikanti L, Singh V, Falco FJE, Cash KA, Pampati V. Evaluation of lumbar facet joint nerve blocks in managing chronic low back pain: A randomized, double-blind, controlled trial with a 2-year follow-up. Int J Med Sci 2010; 7:124-135.

66. Manchikanti L, Singh V, Falco FJE, Cash KA, Pampati V. Effectiveness of thoracic medial branch blocks in managing chronic pain: A preliminary report of a randomized, double-blind controlled trial; Clinical trial NCT00355706. Pain Physician 2008; 11:491-504.
67. Manchikanti L, Singh V, Cash KA, Pampati V, Damron KS, Boswell MV. Preliminary results of a randomized, equivalence trial of fluoroscopic caudal epidural injections in managing chronic low back pain: Part 2. Disc herniation and radiculitis. Pain Physician 2008, 11:801-815.

68. Manchikanti L, Singh V, Cash KA, Pampati V, Datta $S$. Preliminary results of a randomized, equivalence trial of fluoroscopic caudal epidural injections in managing chronic low back pain: Part 3. Post surgery syndrome. Pain Physician 2008; 11:817-831.

69. Manchikanti L, Cash KA, McManus CD, Pampati V, Abdi S. Preliminary results of randomized, equivalence trial of fluoroscopic caudal epidural injections in managing chronic low back pain: Part 4. Spinal stenosis. Pain Physician 2008; 11:833-848.

70. Moher D, Schulz KF, Altman D, for the CONSORT Group. The CONSORT statement: Revised recommendations for improving the quality of reports of parallel-group randomized trials. JAMA 2001; 285:1987-1991.

71. Altman DG, Schulz KF, Moher D, Egger M, Davidoff F, Elbourne D, Gøtzsche PC, Lang T; CONSORT GROUP (Consolidated Standards of Reporting Trials). The revised CONSORT statement for reporting randomized trials: Explanation and elaboration. Ann Intern Med 2001; 134:663-694.

72. Manchukonda R, Manchikanti KN, Cash KA, Pampati V, Manchikanti L. Facet joint pain in chronic spinal pain: An evaluation of prevalence and false-positive rate of diagnostic blocks. J Spinal Disord Tech 2007; 20:539-545.

73. Fairbank JCT, Pynsent PB. The Oswestry disability index. Spine (Phila $\mathrm{Pa}$ 1976) 2000; 25:2940-2953.

74. Carragee EJ. The rise and fall of the "minimum clinically important difference". Spine J 2010; 10:283-284.

75. Carragee EJ, Chen I. Minimum acceptable outcomes after lumbar spinal fusion. Spine J 2010; 10:313-320.

76. Pereira J, Lawlor P, Vigano A, Dorgan $M$, Bruera E. Equianalgesic dose ratios for opioids. A critical review and proposals for long-term dosing. J Pain Symptom Manage 2001; 22:672-687.

Narcotic analgesic converter, GlobalRPh Inc. www.globalrph.com/narcotic. cgi

77. Browner WS, Newman TB, Cummings
SR, Hulley SB. Estimating sample size and power. In: Hulley SB, Cummings SR, Browner WS, Grady D, Hearst N, Newman TB (eds). Designing Clinical Research: An Epidemiologic Approach, 2nd ed. Lippincott, Williams \& Wilkins, Philadelphia, 2001, pp 65-84.

78. Manchikanti L, Cash KA, McManus CD, Pampati V, Singh V, Benyamin RM. The preliminary results of a comparative effectiveness evaluation of adhesiolysis and caudal epidural injections in managing chronic low back pain secondary to spinal stenosis: A randomized, equivalence controlled trial. Pain Physician 2009; 12:E341-E354.

79. Manchikanti L, Singh V, Cash KA, Pampati V, Datta S. A comparative effectiveness evaluation of percutaneous adhesiolysis and epidural steroid injections in managing lumbar post surgery syndrome: A randomized, equivalence controlled trial. Pain Physician 2009; 12:E355-E368.

80. Hotopf M. The pragmatic randomized controlled trial. Adv Psychiatr Treat 2002; 8:326-333.

81. Tunis SR, Stryer DB, Clancy CM. Practical clinical trials. Increasing the value of clinical research for decision making in clinical and health policy. JAMA 2003; 290:1624-1632.

82. Roland $\mathrm{M}$, Torgerson DJ. What are pragmatic trials? BMJ 1998; 316:285.

83. International Conference on Harmonisation of Technical Requirements for Registration of Pharmaceuticals for Human Use. ICH Harmonised Tripartite Guideline. Choice of Control Group and Related Issues in Clinical Trials E10. July 20, 2000.

84. Smuck M, Levin JH. RE: Manchikanti L, Singh V, Falco FJE, Cash KA, Fellows B. Cervical medial branch blocks for chronic cervical facet joint pain: A randomized double-blind, controlled trial with one-year follow-up. Spine (Phila Pa 1976) 2008; 33:1813-20. Spine (Phila PA 1976) 2009; 34:1116-1117.

85. Manchikanti L, Singh V, Falco FJE. In response to Smuck M, Levin JH. RE: Manchikanti L, Singh V, Falco FJE, Cash KA, Fellows B. Cervical medial branch blocks for chronic cervical facet joint pain: A randomized double-blind, controlled trial with one-year follow-up. Spine (Phila Pa 1976) 2009; 34:11161117.

86. Pham Dang C, Lelong A, Guilley J, Nguyen JM, Volteau C, Venet G, Perrier C, 
Lejus C, Blanloeil Y. Effect on neurostimulation of injectates used for perineural space expansion before placement of a stimulating catheter: Normal saline versus dextrose $5 \%$ in water. Reg Anesth Pain Med 2009; 34:398-403.

87. Tsui BC, Kropelin B, Ganapathy S, Finucane $B$. Dextrose $5 \%$ in water: Fluid medium maintaining electrical stimulation of peripheral nerve during stimulating catheter placement. Acta Anaesthesiol Scand 2005; 49:1562-1565.

88. Indahl A, Kaigle AM, Reikeräs O, Holm $\mathrm{SH}$. Interaction between the porcine lumbar intervertebral disc, zygapophysial joints, and paraspinal muscles. Spine (Phila Pa 1976) 1997; 22:28342840.

89. Indahl A, Kaigle A, Reikerås $\mathrm{O}$, Holm $S$. Electromyographic response of the porcine multifidus musculature after nerve stimulation. Spine (Phila $\mathrm{Pa}$ 1976) $1995 ; 20: 2652-2658$.

90. Bhatia MT, Parikh LCJ. Epidural saline therapy in lumbo-sciatic syndrome. J Indian Med Assoc 1966; 47:537-542.

91. Gupta AK, Mital VK, Azmi RU. Observations of the management of lumbosciatic syndromes (sciatica) by epidural saline. J Indian Med Assoc 1970; 54:194-196.

92. Wittenberg RH, Greskötter KR, Steffen $R$, Schoenfeld BL. Is epidural injection treatment with hypertonic saline solution in intervertebral disk displacement useful? (The effect of $\mathrm{NaCl}$ solution on intervertebral disk tissue). $Z$ Orthop Ihre Grenzgeb 1990; 128:223226.

93. Ferrante FM, Paggioli J, Cherukuri S, Ar- thru GR. The analgesic response to intravenous lidocaine in the treatment of neuropathic pain. Anesth Analg 1996; 82:91-97.

94. Arner S, Lindblom U, Meyerson BA, Molander $C$. Prolonged relief of neuralgia after regional anesthetic block. A call for further experimental and systematic clinical studies. Pain 1990; 43:287297.

95. Wertheim HM, Rovenstine EA. Suprascapular nerve block. Anesthesiology 1941; 2:541.

96. Manchikanti L. Interventional pain management: Past, present, and future. The Prithvi Raj lecture: Presented at the 4th World Congress-World Institute of Pain, Budapest, 2007. Pain Pract 2007; 7:357-371. 